\title{
Current HRD trends in the Netherlands; conceptualisation and practices
}

\author{
Kitty Kwakman
}

University of Twente, Faculty of Educational Science and Technology

Department of Curriculum

P.O. Box 217

7500 AE Enschede

the Netherlands

\section{Beatrice van der Heijden}

University of Twente, Faculty of Technology and Management

Department Human Resource Management

P.O. Box 217

7500 AE Enschede

the Netherlands

\section{Jan Streumer}

\section{Ida Wognum}

\section{Simone van Zolingen}

\begin{abstract}
:
Keywords: HRD trends; HRD practices; HRD solutions; Competence development; Employability; Lifelong learning; Delphi method.

\section{Biographical notes:}

Kitty Kwakman is an assistant professor in the domain of human resource development within the faculty of Educational Science and Technology at the University of Twente. She graduated from the Department of Adult Education at the University of Nijmegen in 1992 and defended her $\mathrm{PhD}$ thesis about teacher learning at the workplace at the same University in 1998. Currently, she is working as a teacher and researcher within the HRD-field with a special focus on professional learning, learning at the workplace, learning in communities of practice, and design issues in HRD. She is also one of the lecturers within the international HRD master's programme.

Beatrice van der Heijden is an associate professor in human resource management at the University of Twente. She graduated in 1990 from the Department of Work and Organisational Psychology at the University of Nijmegen and has a PhD (1998) in career development from the University of Twente. Her main research areas are (1) career development (2) employability and (3) ageing at work. Currently she coordinates, among others, a cross-cultural European study on career success among software engineers. She serves as a member of the editorial boards of
\end{abstract}


Career Development International and SAM. Advanced Management Journal. Besides she does some consultancy on Human Resource Management topics.

\section{$1 \quad$ Introduction}

There appears to be a large discrepancy between the reality in HRD practices and contemporary theories on HRD developments [1]. Firstly, training and intentional learning do not occur frequently, and development processes do not happen as systematically and consciously as assumed. Besides, there is evidence that learning opportunities are unequally divided across the workforce, with managers and higher level employees enjoying relatively privileged positions.

It seems obvious that changes in job requirements due to continuously increasing employability demands necessitate to pay attention to the fit between demands and supplies in the domain of professional development [2]. Nevertheless, it may be questioned whether proposed theoretical solutions are applicable and emergent in practice, which is considered as a second discrepancy [3]. Especially in the domain of organisational learning "too often, rhetoric and conceptualisation do not seem to lead to any substantial progress in theory-building or in practice in the field” [4, p. 254].

The discrepancy between HRD theory and practice urges us to confront theorising in the field with empirical outcomes. It is important to find out to what extent attention is paid to organising, shaping and managing the processes of learning and development within working organisations [5]. In order to chart this attention, we will go into HRD developments both from some theoretical perspectives as well as grounded with data gathered during working conferences and interviews with practitioners in the field. The aim of this endeavour is to track down both examples of current developments as described in literature, as well as empirical evidence. Moreover, we want to raise opportunities for HRD practitioners to add new insights to (our) theoretical positions and to explore the potential of a powerful source in building theory within the HRD domain. Both in review and data collection we kept a focus on large companies as the infrastructure for human resource development was expected to be most prevalent in these.

In this contribution we will first go into a thorough literature study aimed at describing current developments. The resulting literature report has been presented to a group of experts ${ }^{1}$ in the field of HRD. The participants have been asked to sketch their vision as to the relevance of the HRD developments for their own working organisation. Besides they have been asked to describe how and why certain developments do influence the HRD area. The remarks of this group, consisting of both academics as well as practitioners, has been used to outline a conceptual framework on current HRD developments and to illustrate the conceptual framework with examples of practices concerning HRD developments in the (late) nineties. In the section on the research methodology extensive information on the research design will be given.

After a presentation of the outcomes, gathered during the working conferences of researchers and company representatives, three in-depth interviews are described. The aim of these interviews was to further explore and interpret new insights gained by means of the working conferences. The first interviewee was the manager HRM Europe of a large global manufacturer producing electronics for consumer and professional markets. The second interviewee was the managing director of an international medium sized consultancy firm covering all aspects of HRM. The third interview was conducted with the general manager and a consultant of a small national consultancy firm specialised in organisational development.

\footnotetext{
${ }^{1}$ See appendix one for an enumeration of the HRD specialists that participated in the working conferences.
} 


\section{Theoretical outlines}

In the coming sections the literature review on HRD developments in the (late) nineties is reported. A division in three areas of description has been made, i.e. developments outside working organisations, developments inside working organisations, and developments within the domain of HRD. After the theoretical outlines and a disquisition of the methodology that has been used, the HRD practices as reported by the participants in the working conferences will be sketched, using the same division in the above-mentioned three areas of description.

\subsection{Developments outside working organisations}

During the last ten years our economy has transformed into a knowledge economy [6-8]. The implications this entails for qualification requirements are considerably [9]. As the life-cycles of occupations and functions offered by organisations have shortened tremendously in the last twenty years, mastering learning and coping strategies and the transferability of these seem to be important topics for psychological and development research in organisations [10].

Yet, only in the last two decades have career researchers started to pay attention to the idea of development throughout one's career [10-12]. This attention shows the growing concern about professional development throughout the working life. Because of the importance of continuously updating knowledge and skills, both the organisation and the individual are held responsible for optimising this development interactively.

Individuals who are able to survive the emergence of the information society, the internationalisation of the economy and scientific and technological progress, are the ones with the most up-to-date knowledge and skills, but also with the capability to continuously build up new expertise requirements [12]. Next to the computerisation, the increasing globalisation, internationalisation, and continuously changing markets and products [13], one can detect changes in customer needs and behaviour (see for example the increase in ecologically sound products). More and more companies privatise and are driven by market economy concepts. Obviously these changes too have many implications for the job requirements of individual employees, as innovation and technological changes poses strong demands on developing communicative and problem-solving skills [14-15].

Information and communication technology (ICT) is an aspect that burdens heavily on the necessary knowledge and skills to perform well in nowadays jobs [16]. Also one can notice an increase in the use of ICT in training and development programs, both in schools as well as in company settings [17-19]. The latter, obviously, aggravates appeals to the individual employee in an era wherein workloads are already impressively high.

Demographic changes like the increase in women participating onto the labour market, the increasing participation of ethnic minorities, ageing of the workforce and the ongoing dejuvenization [9-10] have necessitated the attention for the guidance of life-long employability $[12,20]$. Training and development programs ought to be tailored to the specific needs of classes of employees in order to increase chances of assimilation into the labour market.

Besides, more and more formal certifications are expected in order to guarantee the value of educational activities [see also 21 for a contribution in this research field]. This is why checks as to the content of educational programs and HRD programs, in general, deserve serious attention. In all sectors of higher education and vocational training one can see an increase in the attention towards customer needs. Besides, more and more one strives for a fine-tuning in educational programs with practice [22]. See for example developments like competence-based curricula, dualising and contract education [23].

If the former is combined with the concerns of HRD professionals as to how to cope with the labour shortage in many areas, one can imagine the pressure that is felt by the profession as a whole. 


\subsection{Developments inside working organisations}

In all sectors of the labour market one of the key changes has been the growing urge to monitor organisational aims in order to come to meet flexibility requirements, quality requirements and reduction of costs [6]. A result has been an increasing flattening of organisations, working with business units and outsourcing of non-core tasks.

Besides, a number of developments have taken place, performance-orientation being the most far-reaching. Tayloristic modes of organising have been changed with principles like jobenrichment and team working [24]. In higher level jobs more and more employees telework which enables them a high amount of quantitative flexibility without losing the possibilities to keep in touch with colleagues both inside and outside the organisation (E-mail, internet, mobile telephones, fax).

The increased attention for performance enhancement has enlarged the popularity of the concept of the learning organisation [3.25]. The perspective of the learning organisation is aimed at optimising learning processes of both individual employees as well as the working organisation as a whole [26-29]. Despite the fact that many organisations have faced difficulties in translating the philosophy behind the concept in concrete management activities [30], attention for the subject has led to an increase in developmental activities [31].

More and more top management really pays attention to on-the-job learning, implicit learning processes, knowledge sharing and improvements in working processes, products or services [3236]. Middle management, on the other hand, is expected to guide individual career development by means of job evaluations, assessment of training and development needs, coaching and so on [28]. Yet, in earlier studies [10,12] we have found a scarcity and often a complete absence of managerial actions or measures taken to stimulate the employee's further growth and development of his or her flexibility or versatility. Supervisors often observe a declining learning value (that is to say the value which the function has as nutrient for the employee's further development) of the functions of their ageing employees but do not seem to react to it by enhancing this value. The function becomes void of learning stimuli and new learning challenges. This can even happen in higher level jobs that are extremely important for the organisation and perhaps highly complex and demanding.

Yet, guiding the individual career development is not only the responsibility of management in working organisations [37]. Employees themselves are also expected to put a lot of effort and energy in improving their employability [12]. Both the individual and his or her immediate supervisor should be engaged actively in the development of the individual's capabilities. In addition to training and development programs it is important to provide work experience with opportunities to use talents and to develop professional expertise, preferably in more than one area of expertise. The employees themselves are the ones who have to take an entrepreneurial approach to their own career development [38], and to display a learning attitude. It requires a 'hunger' for activities that benefit further growth.

Opposite to the need to enlarge one's employability, maybe even in an external sense implying that the employee's attractiveness for competitors increases as well, organisations try to guard the commitment from the employee towards the organisation [39]. More and more, flexwerkers, part-time workers and knowledge workers question the need for a high amount of commitment to one particular organisation [7]. Next to the tension between the need to enlarging the amount of employability and guiding the commitment, problems entailed by increasing work loads, burnout issues, etcetera, force the different management layers in a continuing dialogue with the employees in order to deal carefully with the fit between the worker and the job [40].

\subsection{Developments within the domain of HRD}


Obviously, the previously mentioned developments have implications for the performances that are required and thus for the job content and organisation of individual jobs [41]. More and more job requirements have to be expanded with key qualifications like eagerness to learn, flexibility, and readiness to work together in teams [42]. Besides, vocational training is not enough to enable the employee to function qualitatively well throughout the career. Life-long learning and competence development is considered to be the key answer [12,43-44]. Short-term attention for career development in which employees are used to fulfil organisational goals that do exist in the here-and-now do not longer guarantee the individual employability in a longer sense. Due to enormous changes in professional fields life-long employment has been replaced by life-long employability which can only be reached in case both management as well as the employee anticipate as to which professional developments have to be attained [45]. The latter can imply that short-term goals are not longer put in front in each and every case. This brings about the challenging though difficult to reach need for HRD specialists to find an equilibrium between organisational interests (need for high performances) and individual interests, e.g. the need for self-actualisation [45-47]

The increasing attention for life-long learning has led to a change in the way learning processes are organised [20,48]. More and more HRD specialists start to recognise the value of other forms of training and development, for example 'training-on-the-job', computer-supported programs, web-based learning, coaching and support on the job[41,47,49-52]. Besides, training and development is no longer seen as the only solution in order to build up new knowledge and skills. More and more, changes in the organisation of work, such as introducing autonomous teams are seen as a possibility to enlarge competence bases [24,53-54].

The developments that have been outlined so far have altered the role of the HRD specialist. More than before, he or she has to act as a counsellor who facilitates line management and individual employees in carrying out the employability-enhancing and learning activities $[28,30,47,55]$. In order to integrate knowledge management and competence management into the domain of HRD-practitioners, one has to translate strategic decisions into HRD-policies throughout all organisational layers [49,56].

\section{$3 \quad$ Research methodology}

In this section the different research steps will be presented in chronological order. As shortly described before a thorough literature study into current HRD developments has been done followed by a presentation of the resulting literature report to a group of experts during two working conferences (see Appendix 1 for all participants). As subjective judgements on a collective basis were most important in this part of the research, the procedures of the Delphimethod were followed, more specifically those of a "group Delphi which is one of the variants of the Delphi research method [42].

Firstly, sampling was purposive, based on a "snowball" sampling strategy as one of the possible strategies in inductive, theory-building analysis [57]. We tried to compose groups of experts with equal job responsibilities, but from different branches of organisations. Eventually, all experts involved were holding jobs which involved large responsibilities for organising and managing HRD within large organisations (in the profit- as well as the non-profit sector) in the Netherlands. Five experts from the University of Twente (four from the Faculty of Educational Technology, department of Educational Organisation and Management and department of Curriculum Technology and one from the Faculty of Technology and Management, department Human Resource Management) have also participated in the conference, both as interactive sparring partners and to enable a reliable information gathering.

Secondly, participants were asked to sketch their vision as to the relevance of the reported HRD developments for their own working organisation. Subsequently, they were asked to 
describe how and why certain developments do influence the HRD area. In order to prepare themselves, all participants received the literature report and the questions that would be submitted at the working conference in advance.

At the start of both conferences the day chair presented some results on a comparable study on 'company training and development', that had been executed at the end of the eighties. This was important in order to indicate some kind of framework adopted by the research group and the domain in which the study was situated. Next, the chair announced the importance of the chosen strategy to cross-check the literature report and ideas of the research group by means of the experience and insights of the practitioners. Then, research questions one and two were presented:

1. To what extent are the developments that have been outlined in the research report significant for your organisation?

2. Which developments in the domain of training and development have been taken place in your organisation, during the last ten years?

The participants were asked to indicate which HRD development has been most important to their organisation. Subsequently, the participants were asked to indicate what has happened with regard to the indicated topic, what the implications are and what have been the effects. A lot of interaction was possible during this research phase. Besides, at the end of the discussion on questions 1 and 2, there was some time to ask each other questions for clarification.

After a break, research questions 3 and 4 have been presented:

3. Which competencies for HRD-professionals/educational specialists are desirable for the future?

4. Which new competencies for HRD-professionals/ educational specialists do you foresee for the future?

Following this procedure we were able to gain more insight into the extent to which the experts agreed on current HRD developments and their impact as outlined in the theoretical paper.

\section{Results}

In the following three sections, the outcomes of the two working conferences will be reported. The categories of description are similar to the ones that have been used for the theoretical outlines. Firstly, the developments outside working organisations will be treated. Secondly, developments inside working organisations will come up. Finally, the outcomes concerning the developments within the domain of HRD will be discussed.

\subsection{Developments outside working organisations}

The participating HRD specialists, when asked for external developments, mentioned on the one hand the importance of the 'human factor' and on the other hand the impact in the HRD field of the internationalisation and globalisation of markets as well as products. Next to these two main areas of change, some participants reported the influence of technological developments and the implications of the job market.

As far as the first factor is concerned, representatives of DAF and DaimlerChrysler gave a good illustration. Nowadays DAF offers solutions for mobility problems instead of producing cars, trucks etcetera. Because of the fact that unique products are created, individual employees are the most important organisational assets. Competencies have to be built up and quality management has to be a core part of HRM practices. At DaimlerChrysler the importance of the 
human factor has even been formalised. In order to reach high-quality Human Resource Management all HRM-instruments have been integrated and the responsibility for the employee development has been laid down with the employee him or herself. The individual workers are expected to formulate personal development goals and ideas to reach them. Secondly, the focus of the evaluation of the HRD professionals has been changed from their efforts in the area of training and development to the return of investments at the level of the behaviour of the individual employee. The latter meaning that HRD-professionals have to make a connection between developmental needs of individual employees and organisational development goals.

As far as the internationalisation and globalisation are concerned we have five examples of the implications these developments have on a company level. ABN-AMRO has chosen for an approach that focuses on internationalisation on an European scale. As a consequence, internal vocational training institutes have become smaller. Whenever possible, vocational training programs are outsourced and the department of training and development nowadays merely has directing and advising tasks.

For Toshiba Medical, the internationalisation has led to an increasing pressure in terms of the time that is available to train employees. E-mail, globalisation, a growing amount of foreign employees, and the need to commit higher level technicians to the company has led to the need for efficient training programs in much shorter time spans. The primary responsibility for assessing training needs has been moved to the line management in a continuous dialogue with the individual employee. The latter also applies to the TNT Post Group, a holding employing 120.000 people in 120 countries. This decentralisation of the training and education function urges to a translation of strategic higher-order issues to locally feasible practices. In order to provide with this need and to prepare trainers to enormous differences between countries, TNT Post Group has established an academy for trainers.

The fact that internationalisation and globalisation do not automatically lead to a decrease in training and development activities has further been illustrated by the HRD representative of PriceWaterhouseCoopers. Currently, their training budget is around one billion dollar. Their programs are clearly aimed at enlarging the commitment of the employee towards the organisation together with enabling the professionals, who are supposed to be highly employable, to perform qualitatively high. In order to ensure that an employee is suitable to perform services for the organisation's customers, a 'license to audit' has to be granted. Besides, team working is encouraged and is supposed to enlarge one's competence base by exchanging valuable knowledge and skills. For the department of T\&D these developments have led to the system of 'contracting', i.e. preliminary to the performance of activities, agreements are made regarding who, when and where and what subject will be trained.

For Polaroid Europe we can detect a centralisation tendency as a result of the internationalisation. Although the different locations are expected to work closely with the central training department in the United States, in practice it is not quite clear in how far one is responsible for formulating strategic goals.

As far as the third factor, i.e. technological developments is concerned, both the representative of Hollandse Signaal Apparaten and the one of the Dutch Air Force went into its consequences. It was reported that next to information and communication technology, advanced technological knowledge of material and products is indispensable for current functioning of these working organisations. At Hollandse Signaal Apparaten one signals the need to get hold of experts both for internal use as well as for their customers. In order to respond to this need three different types of educational programs have been developed, i.e. education for their own employees, education for customers who have bought their materials, and education for their future customers.

For the Dutch Air Force, training and education has always been a focal point. The technical and highly specific requirements for flying a certain plane, and also the demands of quality and 
safety have forced them to large investments in training and development. The responsibility for making reliable assessments of the training needs has been laid down at the line management.

As regards the last mentioned topic of the influence of the job market, three organisations have referred to it and have indicated its consequences in the domain of HRD. Because of the fact that the University of Twente has a surplus of employees in relation to the available jobs and the costs that are brought about by this, the University has started to pay attention to retraining and job market preparation programs. Next to a mobility centre that has been established with the aim of enlarging one's knowledge and skills, outplacement programs have been developed.

In the Martini hospital, on the contrary, one has great difficulties to find qualified personnel. Part of the problem is due to the minor interest in health service jobs, but also the geographical location (in the North of the Netherlands). Aside from that, new strict laws concerning times to rest and recovery for health professionals have exaggerated occupational problems. Moreover, the dejuvenization and the ageing of the working population necessitate paying attention to the implications of the increasing workload for the elderly. This urge the ARBO-dienst (services of conditions of employment) and the department of Training and Development to put the topic of the guidance of mobility and employability, and the ways this can be reached, high on the agenda. Similarly, the AWVN (General Employers' Association in the Netherlands) has made the topic of the guidance of employability to be the central point of attention. More emphasis on the individual career development and a broader definition of training goals are elevated into the key points of attention.

Comparing the developments mentioned in the theoretical outline one can conclude that participants do stress the same three main factors lying behind the current developments, i.e. economy, technology, and labour market. Although the outline also describes developments in the area of legislation, vocational education, or social-cultural developments, the participants did not mention about these particular developments. This does not imply that these latter types of developments do not occur, but that they are regarded of minor importance in affecting the HRD field.

\subsection{Developments inside working organisations}

As indicated in the corresponding section in the theoretical outlines, many organisations are forced to re-orientate on their organisational goals and to reconsider their present organisation of jobs. Representatives from Generali Assurances, Canisius Hospital, Hoogovens and Connexxion give accompanying examples.

For Generali Assurances, the change towards a customer-oriented organisation has led to a centralisation of the output norms, i.e. customer satisfaction and cost awareness. Especially the focus on customer awareness has implied an enormous increase in training costs. At the Canisius hospital, the focus of customer satisfaction has led to multidisciplinary tasks for the medical staff. The department of training and education has been outsourced to the ARBO-dienst (service of conditions of employment). Besides, a reorganisation leading to a flattening of the organisation has led to new HRD questions. Interdisciplinary team work for professionals and delegating management skills being two examples. In this hospital, competence management, a broadening of tasks and learning strategies are key issues in current personnel management tasks.

At Hoogovens, a reorganisation has led to the introduction of business units with their own responsibilities, and that are delegated to the line management, in order to upgrade the professional expertise of each individual employee. A problem one encounters is the lack of an overview of developments in the specific professional domains and in the training programs that are given. In order to enable the HRD function to facilitate business management in the different units, one should have more insight into the specific requirements in the jobs of the professionals in each business unit. 
Connexxion, a transport company, which is the result of a fusion, concentrates on management development and education management in consideration of the guidance of competencies and in order to respond to the need for performance enhancement. Previously used job descriptions and performance evaluations are currently substituted by elaborated reports on systematically determining and developing competencies.

The perspective of the 'learning organisation' forms the basis of the management philosophy of Gamma Holding, a textile industry company. Its philosophy is based on three conditions, i.e. delivering a high quality, using advanced technology and applying cunning logistics. In the Netherlands, Gamma Holding employs 2200 people, world-wide 10.000. A reorganisation implied a change from a labour-intensive to a capital-intensive company meaning a change in range of products as well. At the moment one can characterise the company as process-driven and results-oriented, with a lot of investments in its innovative and technological capacities. Team building is used as a means to consciousness-raising for the philosophy of the learning organisation. Competence management is one of the building pillars in this sense.

As far as the subject of commitment is concerned, a clarifying example can be found in the AKZO strategy where one, in order to enhance the individual commitment, puts a lot of energy in formulating norms and values people can identify with. Also at Connexion one tries to establish longer term working relationships by investigating which factors are highly valuable for people. For Hollandse Signaal Apparaten, on the other hand, commitment is not conceived to be a problem. The representative reports relatively long terms of duration of the employees within the company.

Comparing these examples with the theoretical outline, it is obvious that theory and practice both stress structural as well as cultural changes taking place within work organisations in order to attain organisational goals as well as to improve the level of performance.

\subsection{Developments within the domain of HRD}

Apparently, in the outlines that are given up to now, one can detect a change in main strategy that can be characterised by means of a transition from 'education-minded' towards 'life-long learning-minded'. Many learning processes are founded on the need to enlarge one's employability. For example, the Rabobank (a Dutch banking organisation) academy has formulated as its aim; the transition from life-time employment towards life-long employability. Besides, the representative reports that more and more attention is paid to working in multidisciplinary teams, guiding one’s own career, taking initiatives and pro-active thinking and acting.

The Dutch Railways has established a mobility centre that both supports employees and prevents career problems. Each employee is enabled to have a career advice every three years. The Academic Hospital in Utrecht, nowadays, pays more attention to Human Resource Management activities because of the fact that there is too much outflow of personnel. Firstly, more training and education possibilities have been created. Secondly, a job satisfaction survey has been done and finally, measures to enlarge the amount of job satisfaction have been undertaken.

In all examples mentioned before one can detect a trend in which the responsibility for HRM activities are laid down with the line management. More and more HRD specialists act as advising partners (see for example at Start, an employment agency in the Netherlands). Training and education are more than ever outsourced while the existing departments of training and education are used especially for management development trajectories (see for example the socalled Business School at the AWVN (General Employers' Association in the Netherlands).

At Vredestein, the HRD managers take care of signalling new developments, trying to find possibilities in the job market, formulating strategic plans and so on, while in the past they mostly spent a lot of time taking care of all training and education activities. 
As far as the specialism of competence management is concerned, the representative of PriceWaterhouseCoopers mentioned the birth of new jobs in the field, like knowledge managers, electronic learning experts and information technologists. All these jobs are aimed at building up knowledge and skills bases in individual employees throughout the organisation and in an ongoing sense, i.e. during the entire career.

In comparison with the theoretical outline, a first impression of the developments mentioned by practitioners is that they resemble the developments determined theoretically to a large extent. However, a shift in the way learning processes are organised, as predicted in theory, can hardly be recognised in practice. Although the need for this shift is recognised in practice, examples of other ways of organising learning are hardly given. This may lead us to conclude that the undertaken activities are not in line yet with the ideas and wishes in this respect.

\section{Conclusions}

The confrontation between theory and practice that was deliberately staged in the working conferences appeared to be fruitful as it yielded some new insights to our theoretical views. Firstly, a diversity of working organisations largely recognises the developments as described in literature to a certain extent. So, the outline appears to be suitable to describe and further analyse HRD developments. Nevertheless, all experts agreed that it only suits large organisations or multinationals, and that it does not apply to small and medium sized enterprises as well as to nongovernmental organisations. It was also remarked that the outline should pay more attention to international developments, as a lot of organisations will face an increasing globalisation and internationalisation.

Secondly, although the experts recognised and consolidated a lot of different developments, it became clear that not all developments are of equal importance within specific organisations in the same time period. Organisations do face several challenges, which may be provoked by developments as described, but precise implications of different developments vary from organisation to organisation. As illustrated one specific development can lead to a large variety of different consequences, dependent on the context and the extent to which other developments apply. This is partly due to the fact that many of the developments are intertwined, so that it is not easy at all to differentiate between the developments that have been outlined.

Thirdly, we also have to conclude that almost all HRD developments derive from developments both inside as well as outside organisations because of the fact that HRD activities and goals do change as a result of these developments. Consequently, developments regarding the HRD-domain hardly arise from the domain itself, as the domain is mostly reactive to outside changes and to new demands and challenges. What makes it even more complex is that responses of the HRD-domain seem to vary according to the specific situation of the organisation. As the results reveal, every organisation takes other measures to cope with new developments. Actually, this is in line with other reviews of HRD developments and functions which apply also outside the Netherlands [6,15,44,58].

\section{$7 \quad$ Limitations and some supplementary data}

Although the working conferences revealed the applicability of the theoretical outline describing developments going on in large organisations, the outline is not directly suitable to get insight into specific processes within one single organisation. In order to further explore the problem of understanding why organisations apply specific HRD solutions, three more representatives of organisations operating in rapidly changing markets, but varying in size, were interviewed. In these interviews the interviewers deliberately used an open approach to maximise the opportunity of getting new information [57]. Thus, interviewees were asked to give their opinion regarding 
current developments that have a large impact on the HRD domain within their own working organisations.

\subsection{Philips Components}

Philips Components is one of several Product Divisions that make up Royal Philips Electronics. Founded in 1891, Philips today is a global company with sales around \$34 billion, a workforce of 234,000, and sales and service outlets in 150 countries. It comprises of five global business groups, has more than 60 factories in 18 countries in Europe, North and South America, and the Asia-Pacific region, and sales organisations in 39 countries, all connected by an integrated logistics system providing fast, reliable supply anywhere in the world.

Philips Components plays a key role in providing the innovative technology base that supports Philips' leadership in mass consumer and professional markets such as TV, video, audio, mobile communications, lighting, medical and household appliances. Additionally, Philips is a major partner with the world's leading original equipment manufacturers (OEMs) in consumer electronics, PC and PC related, telecommunications and automotive markets. With its strong research facilities and industrialisation capabilities, Philips Components is in an excellent position in bringing technologies (products and processes) to countries at different stages of development.

As an internationally company operating in one of the world's most aggressive market areas, Philips Components knows that its greatest asset lies in the quality of the people in their organisation. This asset is embodied in Philips' five corporate values that are vital in this respect; cross-functional teamwork, challenging assignments, instant feedback on performance, development of personal skills and performance-related pay. In striving to become a world-class company, it is the quality of their people that they consider of paramount importance. It is them who determine the success of the company, today and in the future.

The quality of leaders is considered to be the critical factor in realising ambitious business goals. These goals are defined as achieving world-class standards which are reached by strengthening the brand image, by selecting the right portfolio, by streamlining manufacturing processes, by improving internal procedures, by focusing on technological capabilities, and by raising their investments in research and development. Six leadership competencies (showing determination, focusing on the market, finding better ways, demanding top performance, inspiring commitment, developing self and others) define the behaviour that is required to achieve business success. This so-called Philips Leadership Competencies framework has been defined on the basis of Philips business goals and the organisational capabilities required to achieve these goals. It makes clear what leadership capabilities Philips requires, and what kind of personal behaviour identifies managers as excellent leaders.

The framework provides a balanced approach, stating the importance of task aspects while recognising that results are obtained through people. The leadership competencies clearly show people what Philips expects from leaders and they provide a meaningful yardstick for measuring progress. They indicate where improvement needs to be made and supply the tools to reinforce strengths and close any competency gaps. The Leadership Development Pack (a tool for selfdevelopment), the Leadership Development Questionnaire (a multi-rater feedback tool) and Development Centres are examples of these tools.

The Philips Leadership Competencies framework helps the managers to plan their own development and the development of others. They provide the language and the tools to suit the development efforts and the leadership profile with the company needs. Strongly supporting the business goals, they help the managers to improve their management behaviour and decision making. Furthermore, they serve as a challenging target for all talented individuals who want to play a leadership role in the company. Besides, the framework does not only serve as a guideline and target for the personal development of current and future leaders, it also provides the organisation with a clear, Philips-wide, reference framework for selection and development. As 
such, it enables to measure performance, to benchmark practices against world-class examples and to decide on actions.

Using the Philips Leadership Competencies as the foundation for human resource development processes is considered to be an important step forward. It reinforces the change in the Philips culture, taking members towards a new and different management style. A style in which managers not only organise and conduct their businesses, but have the vision and drive to inspire and lead those around them to world-class performances.

\subsection{GITP}

GITP is a medium sized consultancy firm specialised in HRM services for government, public management, the health care sector, as well as for management in the profit sector. It has been founded fifty years ago. The portfolio of GITP can be entitled to be a full-service one, that is, comprising all aspects of Human Resource Management: recruitment, selection, assessment and career development as well as the strategic aspects of HRM. Its roots lie in the academic world and from the outset there have been strong ties with two Dutch Universities. In the Netherlands there are over 200 consultants based in 15 locations. In 1992 turnover was NLG 35 million, and by 1999 this had risen to NLG 85-90 million.

GITP has strong European ambitions, which it is realising via networks and joint ventures with similar HR consultancy firms in various European countries, as well as through its own branches in Belgium (offices in Antwerp, Brussels and Gent) and Germany (offices in Berlin, Düsseldorf and Frankfurt) and, before, in other European countries as well. Moreover, GITP undertakes HRM projects outside Europe also for several multinational companies. As their clients became increasingly international, GITP followed their clients with international projects in order to keep serving them.

GITP's search \& selection specialists work to fill vacancies on the instructions of companies and institutions in both the profit and non-profit sector. For the final selection of candidates GITP offers individual assessment programs tailored to the specific recruitment situation. Each project is carried out under the guidance of a GITP recruitment consultant, but the client makes the final selection. Assessment programs, which take place in Dutch, French, English and German, are held at GITP units, at the client's premises (in-company) or residentially. The programs usually last one to one and a half days.

In addition to assessment and career advice, the consultants at GITP are active in job analysis, competence profiling and post-assessment development and coaching. GITP also has an interim management department, which seconds managers to posts in a variety of sectors. Besides, they do not only offer training courses for managers at all levels, for staff and supervisory employees, and for specialists, but also in-company training courses specially tailored to the needs and culture of the company concerned. Besides, individual guidance, training or coaching is also available as is organisational consultancy.

GITP departs from the idea that the success of business and human resource improvement programs is a joint responsibility. Consultants feel responsible not only for the professional development but also for the practical implementation of effective business and human resource practices. Consequently, the interaction between GITP and its different customers is regarded as highly significant, implying that the proposed solutions more and more are determined in cooperation with the customers. Besides, effective practice in a multinational and intercultural setting requires GITP to deal effectively with different national and organisational cultures. Therefore, GITP has a broad international network that guarantees the required professional expertise at both the local and international level. As the organisations in the international network operate in a wide variety of countries and cultures GITP can bring in consultants with an profound knowledge of the local language and context wherever this is required. 
In this rapidly changing market of consultancy issues, GITP plans to expand its activities in more and more countries with a strong focus on Europe. However, not only the amount of countries will influence the work of consultants, but also the kinds of requests for consultancy services will change enormously. Current developments within organisations will call for attention to employability and to the importance of investing in a further career development of individual employees. Next to this, the increase in the share of women in the labour market, the 'share-holders value' and the development of work ethics are expected to be key determinants of training and consultancy requests by the customers in the near future. Besides these, there is a growing need for reflections upon individual careers within all kinds of organisations. The latter has already meant a shift from an emphasis on assignments in the domain of recruitment and selection to career development and assessment problems.

In order to cope with the enhanced requirements, all consultants and trainers have to have large amounts of insight into Management Development and employability, while these are the main themes, in nowadays practice. Furthermore, GITP's strategy is based on the idea that each consultant is capable of acting both as a specialist as well as a generalist. He or she must be competent at, at least, two domains of expertise. As an example, a clinical psychologist who additionally knows a lot of HR-systems in companies could be highly valuable as a consultant for GITP. Due to long-lasting customer-consultant relationships the development of professional expertise in a broader sense, apart from the specific domains of the assignments that are handled during the existing relationship, deserves continuous attention.

\subsection{Triam knowledge management}

TRIAM is a small Dutch company operating in the field of organisational development services with a main focus on large companies. TRIAM has a workforce of 44 consisting of educational professionals with expertise in consultancy, and educational design and development. Core competencies of TRIAM within the consultancy area have to do with: 1) knowledge management, 2) training problem, i.e. research, design and development, implementation, and service of training courses, 3) total quality, 4) business documentation and information, i.e. research, design and development, production, implementation, and service of business documentation and information, and 5) competence management.

The service of TRIAM also addresses design areas such as desktop publishing, graphic design and advertising, care and supervision of printed matter, and translation (from and into Dutch). Originally being a training consultancy firm, TRIAM services were mostly consulted by heads of training departments. Since 1995 TRIAM strives for new clients from the strategic management level within organisations.

As TRIAM operates in a changing and partly unknown market, they monitor the requests of their clients intensively. The following new challenges were faced in the last couple of years. Firstly, clients want projects to be finished increasingly faster, so there is less time available to finish projects. Secondly, more and more projects are only carried out once, so that the service delivered is relatively new and has to be newly designed. Thirdly, clients request for ICT-based courses to be offered on the Intranet or the Internet which poses new design problems. Fourthly, clients tend to prefer business administrators in stead of educationalists which really offers a threat to TRIAM whose consultants are predominantly educationalists.

In order to cope with these changes TRIAM undertook diverse activities and measures. They invested in a quality system in which senior consultants critically review products of fellow consultants before they are delivered to clients. Moreover, an ISO-9001 certificate was strived for and attained. Furthermore, the demands of knowledge in ICT and in business administration were fulfilled partly fulfilled by recruiting new consultants that already possess this knowledge. On the other hand TRIAM offered training in ICT and in 'commercial thinking' to the existing personnel together with training programs aimed at addressing new clients like SME's. Next to these 
activities and measures, a new career development policy has been implemented. Every year TRIAM constructs an organisational profile for the coming 5 years as well as one for the coming 2 or 3 years. This profile determines goals and activities of each department in the coming years whereas individual consultants have to align their own career plans and activities to these goals. This is achieved by conducting individual career development interviews and by making clear arrangements about work outcomes and development activities to be undertaken.

\subsection{Conclusions and implications}

Summarising the main outcomes of these three interviews we may conclude that they confirm the newly gained insights that have been derived from the working conferences. We clearly see that Philips as well as GITP and TRIAM invest heavily in raising the quality of their products and services in order to remain competitive at a rapidly changing market. Despite their orientation towards quality, inspired by both economical and technological developments, they all raised their own strategies in reaching this quality.

Actually, the different strategies that are chosen do address different aspects of human resource development. Philips focuses on leadership and leadership competencies by assigning leaders as key actors in striving for excellence. GITP deliberately tries to cover a broader domain of professional expertise at the organisational level. They try to do so by putting larger demands on the professional expertise of their individual employees whom have to broaden their experience continuously in order to keep up with new consultancy requests. TRIAM uses a mix of diverse HRM instruments to raise the quality of their service. Next to implementing a quality control system they also make use of recruitment, training, and career development plans.

Similar developments going on outside organisations do influence HRD and HRD responses within organisations, but they do not automatically lead to the same types of responses [59]. Obviously, processes and dynamics within organisations seem to play a major role in determining these responses. Understanding these processes and dynamics might be an interesting topic in HRD research that will deliver worthwhile insights to better understand HRD practices.

An interesting research activity might consist of large-scale survey research aimed at determining the relationship between current HRD practices and its consequences for individual performance, career success and satisfaction among employees. Finally, it is their opinion on the suitability of managerial and individual career activities in the light of further development opportunities that counts. In order to stay employable, both management and individual employees should continuously pay attention to the fit between organisational and environmental demands and employees' capabilities.

\section{Appendix 1}

List with names and background of participants in working conferences

Hier: namen en typeringen bedrijven (groot/klein, sector, internationaal of nationaal, profit of non-profit) 


\section{References}

1 Poell, R. and Van der Krogt, F. (2001). Learning at the workplace reviewed: Theory confronted with empirical research. In J.N. Streumer (Ed.), Perspectives on learning at the workplace. Proceedings second conference on HRD research and practice across Europe 2001 (pp. 47-55). Enschede: University of Twente, Faculty of Educational Science and Technology.

2 Gaspersz, J. and Ott, M. (1996). Management van employability. Nieuwe kansen in arbeidsrelaties [Management of employability. New opportunties in labour relations]. Assen: Van Gorcum/Stichting Management Studies.

3 Senge, P.M. (1990). The fifth discipline: The art and practice of the learning organization. Londen: Century Business.

4 Harrison, R. (2000). Learning, knowledge productivity and strategic progress. International Journal of Training and Development, 4, 244-258.

5 Streumer, J.N., Van der Klink, M.R., and Van de Brink, K. (1999). The future of HRD. International Journal of Lifelong Education, 18, 259-274.

6 Baets, W. and Van der Linden, G. (2000). The hybrid business school: Developing knowledge management through management learning. Amsterdam: Pearson Education.

7 Kessels, J.W.M. (2001). Verleiden tot kennisproductiviteit [Enticing into knowledge productivity]. Inaugurele rede Universiteit Twente [Inaugural lecture, University of Twente, The Netherlands].

8 McLagan, P.A. (1999). As the HRD world churns: Trends, forces, and the cusp. Training \& Development, December, 20-30.

9 Van Zolingen, S. J. (1998). Op zoek naar sleutelkwalificaties [In pursuit of key qualifications]. Pedagogische Studiën, 75, 295-310.

10 Boerlijst, J.G., Munnichs, J.M.A. and Van der Heijden, B.I.J.M. (1998). The older worker in the organization. In: P.J.D. Drenth, Hk. Thierry and De Wolff, Ch.J. (Eds.), Handbook of Work and Organizational Psychology (Vol. 2, pp. 183-213). London: Psychology Press.

11 Hall, D.T. (1986). Breaking career routines: Midcareer choice and identity development. In: D.T. Hall and Associates (Eds.), Career development in organizations (pp. 120-160). San Francisco: Jossey-Bass.

12 Van der Heijden, B.I.J.M. (1998). The measurement and development of professional expertise. A retrospective study among higher level Dutch professionals. PhD-thesis. University of Twente, the Netherlands. Enschede: PrintPartners Ipskamp. Crowned with the NITPB-price 1998 (Northern Institute for Applied Psychology and Organizational Psychology in the Netherlands). 
13 Tjepkema, S. (1998). Het concept van de 'lerende organisatie' en levenslang leren [The concept of the learning organization and lifelong learning]. In J. Brandsma (Ed.), (On)mogelijkheden en perspectieven van een leven lang leren (pp. 39-56). Den Haag: SDU.

14 Horwitz, F.M. (1999). The emergence of strategic training and development: The current state of play. Journal of European Industrial Training, 23(4/5), 180-190.

15 OECD (2000). A new economy? The changing role of innovation and information technology in growth. Parijs: OECD.

16 Wilbrink, B. (1998). Levenslang leren en informatie- en communicatietechnologie [Life long learning and ICT]. In T.T.D. Peetsma and M.L.L. Volman (Eds.), Bevorderende en belemmerende factoren voor een leven lang leren (pp. 171-185). Den Haag: SDU.

17 Boogert, K. and Wagenaar, J. (1999) (Eds.). Leren in de BVE: Uitdagingen, inzichten, mogelijkheden [Learning in adult vocational education: challenges, insights, and opportunities]. 's Hertogenbosch: CINOP.

18 Rosenberg, M.J. (2001). E-learning: Strategies for delivering knowledge in the digital age. New York: McGraw-Hill.

19 Voogt, J. and Odenthal, L. (1999). Met het oog op de toekomst: Een studie naar innovatief gebruik van ICT in het onderwijs [With an eye on the future: A study into emergent practices of ICT in education]. Zoetermeer: PROMITT.

20 Thijssen, J.G.L. (1997). Leren om te overleven: Over personeelsontwikkeling als permanente educatie in een veranderende arbeidsmarkt [Learning for survival: employee development as lifelong education in a changing labour market]. Inaugurele rede Universiteit Utrecht [Inaugural lecture University of Utrecht, The Netherlands].

21 Scholten, A. (2001). Facilitating mobility of workforce through international recognition of competencies. In J.N. Streumer (Ed.), Perspectives on learning at the workplace. Proceedings second conference on HRD research and practice across Europe 2001 (pp. 315-321). Enschede: University of Twente, Faculty of Educational Science and Technology.

22 Onstenk, J. (2000, September). Core competencies in the Dutch qualification structure. Paper presented at the European Conference on Educational Research, Edinburg, UK.

23 Schlusmans, K., Slotman, R., Nagtegaal, C. and Kinkhorst, G. (1999). Competentiegerichte leeromgevingen [Competency-based learning environments]. Utrecht: Lemma.

24 Onstenk, J.H.A.M. (1997). Lerend leren werken. Brede vakbekwaamheid en de integratie van leren, werken en innoveren [Learning to learn working. Occupational competence and the integration of learning, working, and innovating]. Academisch Proefschrift Katholieke Universiteit Nijmegen. Delft: Eburon [PhD thesis University of Nijmegen, The Netherlands].

25 Brinkerhoff, R.O. and Gill, S.J. (1994). The learning alliance. Systems thinking in Human Resource Development. San Francisco: Jossey-Bass Publishers. 
26 Bomers, G.B.J. (1989). De lerende organisatie [The learning organization]. Nijenrode: Universiteit of Management Science.

27 Mandl, H. and Reinmann-Rothmeier, G. (1995). Leren in organisaties [Learning within organizations]. In J.J. Peters, R.J.J.M. van Ommeren, P.W.J. Schramade and J.G.L. Thijssen (Eds.), Gids voor de Opleidingspraktijk. Houten: Bohn Stafleu Van Loghem.

28 Marsick, V.J. and Watkins, K.E. (1999). Facilitating learning organizations: Making learning count. Aldershot: Gower.

29 Swieringa, J. and Wierdsma, A.F.M. (1990). Op weg naar een lerende organisatie [Towards a learning organization]. Groningen: Wolters-Noordhoff.

30 Garvin, D.A. (2000). Learning in action: A guide to putting the learning organization to work. Boston: Harvard Business School Press.

31 Senge, P., Roberts, C., Ross, R., Smith, B., Roth, G. and Kleiner, A. (1999). The dance of change: The challenges to sustaining momentum in learning organizations. New York: Doubleday.

32 Gourlay, S. (2001). Knowledge management and HRD. Human Resource Development International, 4, 27-46.

33 Kessels, J.W.M. (1996). Leren in arbeidsorganisaties: De opkomst van de kenniswerker [Learning in companies: The rise of the knowledge worker]. In B. van Gent (Ed.), Opleiden en leren in organisaties: Ontwikkelingen, benaderingen, onderzoekingen (pp. 52-68). Amsterdam: Boom.

34 Nonaka, I. and Takeuchi, H. (1995). The knowledge-creating company: How Japanese companies create the dynamics of innovation. New York: University Press.

35 Smit, C.A. (1995). Tacit knowledge. In J.W.M. Kessels and C.A. Smit (Ed.), Kennisproductiviteit. Opleiders in Organisaties, Capita Selecta 26. Deventer: Kluwer.

36 Weggeman, M.C.D.P. (1997). Beter leren in organisaties [Better learning in organizations]. In J.J. Peters, R.J.J.M. van Ommeren, P.W.J. Schramade and J.G.L. Thijssen (Eds.), Gids voor de Opleidingspraktijk. Houten: Bohn Stafleu Van Loghum.

37 Kuijpers, M. (2001, January). Career development competencies. Paper presented at the Second Conference on HRD Research and Practice across Europe 2001, Enschede, The Netherlands.

38 Rhebergen, B. and Wognum, I. (1996). Supporting the career development of older employees: an HRD point of view. In: E.F. Holton (Ed.), Academy of Human Resources Development (pp. 544-551). Conference Proceedings. 
39 Bruel, M. and Colsen, C. (1998). De geluksfabriek. Over het binden en boeien van mensen. [The hapiness factory. About commiting and fascinating people]. Schiedam: Scriptum Management.

40 Kwakman, C.H.E. (in press). Work stress and work-based learning in secondary education: Testing the Karasek model. Human Resource Development International.

41 Torraco, R.J. (1999). Integrating learning with working: A reconception of the role of workplace learning. Human Resource Development Quarterly, 10, 249-270.

42 Van Zolingen, S.J. (1995). Gevraagd: sleutelkwalificaties. Een studie naar sleutelkwalificaties voor het middelbaar beroepsonderwijs [Demanded: Key qualifications. A study into key qualifications in intermediate vocational education. Academisch Proefschrift Katholieke Universiteit Nijmegen [PhD thesis University of Nijmegen, The Netherlands].

43 Brandsma, J. (Ed.) (1998). (On)mogelijkheden en perspectieven van een leven lang leren [Opportunities and perspectives of life long learning]. Den Haag: SDU.

44 Garavan, T.N., Heraty, N. and Barnicle, B. (1999). Human resource development literature: Current issues, priorities and dilemmas. Journal of European Industrial Training, 23(4/5), 169-179.

45 Kwakman, C.H.E. (1999). Leren van docenten tijdens de beroepsloopbaan. Studies naar professionaliteit op de werkplek in het voortgezet onderwijs [Teacher learning during the career]. Academisch Proefschrift Katholieke Universiteit Nijmegen [PhD thesis University of Nijmegen, The Netherlands].

46 Confessore, S.J. and Smith, D.H. (1998, March). The relationship between individual and collective learning in the learning organization: Its role and effect in defining the profession of HRD. Paper presented at the Conference of the Academy of Human Resource Development, Oak Brook, United States.

47 Poell, R.F. (1998). Organizing work-related learning projects: A network approach. Academisch Proefschrift Katholieke Universiteit Nijmegen [PhD thesis University of Nijmegen, The Netherlands].

48 Van der Krogt, F.J. (1995). Leren in netwerken. Veelzijdig organiseren van leernetwerken met het oog op humaniteit en arbeidsrelevantie [Learning in networks: The many-faceted job of organizing learning networks with a view to humanity and work relevance]. Utrecht: Lemma.

49 Bassi, L., Cheney, S. and Lewis, E. (1998). Trends in workplace learning: Supply and demand in interesting times. Training \& Development, 52(11), 51-77.

50 Bastiaens, T.J. (1997). Leren en werken met electronic performance support systems: Een effectevaluatie [Learning and working with electronic performance support systems: An evaluation of effects]. Academisch Proefschrift Universiteit Twente [PhD thesis University of Twente, The Netherlands].

51 Teurlings, C.S.J. (1993). Leren tekstverwerken: Een nieuw perspectief [Learning wordprocessing: A new perspective]. Academisch Proefschrift Katholieke Universiteit Brabant. 
Alblasserdam: Haveka [PhD thesis University of Brabant, The Netherlands].

52 Van der Klink, M.R. (1999). Effectiviteit van werkplek-opleidingen [Effectiveness of on-thejob-training]. Academisch Proefschrift Universiteit Twente [PhD thesis University of Twente, The Netherlands].

53 Stahl, T., Nyhan, B. and D’Aloja, P. (1993). De lerende organisatie: Een visie op human resource development [The learning organization: An perspective on human resource development]. Brussel: Eurotecnet.

54 Tjepkema, S., Kessels, J.W.M., Papas-Talen, A.N. and Smit, C.A. (Eds.) (1999). Leren (werken) in zelfsturende teams [Learning (to work) in self-managing teams]. Opleiders in Organisaties. Capita Selecta 37. Deventer: Kluwer.

55 Ellinger, A.D. (1998, March). The beliefs of managers as facilitators of learning in learning organizations. Paper presented at the Conference of the Academy of Human Resource Development, Oak Brook, United States.

56 Visser, M., Mulder, M. and Geelen, A.P.C. (1998). Kerncompetenties en opleidingsbeleid in de praktijk [Key competencies and training policy in practice]. Opleiding \& Ontwikkeling, 11(10), 17.

57 Miles, M.B. and Huberman, A.M. (1994). Qualitative data analysis: An expanded sourcebook (sec. edition). Thousand Oaks: Sage.

58 Willmore, J. (1999). Four HRD Scenarios of the future: Any could happen. Training \& Development, December, 38-41.

59 Poell, R. F., Van der Krogt, F.J., Vermulst, A., Den Boer, P. and Hövels, B. (2001). Veranderingen in werk, competenties en leerwegen van vakmensen in arbeidsorganisaties [Changes in work, competencies and learning routes of professionals in working organisations]. Paper presented at the ORD 25-27 June. Amsterdam. 